\title{
THE EXPANSION OF THE CLASSROOM THROUGH MOBILE IMMERSIVE LEARNING
}

\author{
Josef Buchner $^{1}$ and Alberto Andujar ${ }^{2}$ \\ ${ }^{1}$ University of Teacher Education St. Gallen, Müller-Friedberg-Straße 34, CH-9400, Switzerland \\ ${ }^{2}$ University of Almeria, Crta. de Sacramento s/ $n$, La Cañada, Almeria, 04120, Spain
}

\begin{abstract}
In this article we describe how mobile devices enable immersive learning experiences. Expensive Head Mounted Displays (HMDs) are a thing of the past, as even inexpensive alternatives in combination with a smartphone make it possible to immerse oneself in virtual worlds. Learners then take these worlds as realistic, which can lead to cognitively and physically behaving as in real life. Immersive learning then may contribute to the dissolution of space and time and to more authentic learning experiences. The limitations of spatial classrooms can thus be broken down and expanded more and more, in the K-12 classroom as well as in higher education.
\end{abstract}

\section{KEYWORDS}

Virtual Reality, Augmented Reality, Mobile Immersive Learning, Authentic Learning

\section{INTRODUCTION}

"What killed the mobile learning dream" asks Traxler (2016) in his eponymous article. For him the potential of mobile devices for teaching and learning has not yet become reality in education. Rather, traditional pedagogical approaches are used, and educational content is prepared to fit on a small screen. This criticism is reminiscent of early definitions of mobile learning, as the technological perspective was in the foreground. Quinn (2000), for example, recognized mobile learning just as learning "on" or "through" mobile computers whereas for Kukulska-Hulme (2005) the physical mobility provided by handiness made a difference to other educational technologies. The potential of mobile learning goes far beyond these technological perspectives, including the possibility to offer authentic and collaborative learning environments (Cook \& Santos, 2016), create learning tasks like designing multimedia artefacts (Arnedillo-Sanchez \& Tangney, 2006; Stevenson, Länsitie, Kogler, \& Bauer, 2015), bridge indoor and outdoor classroom activities (Sharples, Arnedillo-Sanchez, Milrad, \& Vavoula, 2009) and access to explorative as well as gamified problem-based learning scenarios (Klopfer \& Sheldon, 2010; Squire \& Jan, 2007). When we talk about mobile learning, we have to take a second aspect of learning into account: informal learning. Kids, adolescents and adults are living in an increasingly digital, hence connected world, which also leads to a more mobile lifestyle. Tourists discover cities with Google Maps, backpackers book their room on the way from one destination to the next and history lovers explore monuments in Prague and Pisa through Augmented Reality (Duguleana, Florin, Postelnicu, Brondi, \& Carrozzino, 2016; Kysela \& Štorková, 2015). Based on these changing processes Sharples et al. (2009) define mobile learning as a personal and public "exploration and conversation across multiple contexts, amongst people and interactive technologies" (Sharples et al., 2009, p. 237). While informal learning is characterized as a time and space independent process which basically takes place outside the classroom, formal education is defined by fixed physical spaces and given lesson times (Kearney, Schuck, Burden, \& Aubusson, 2012). Here, Traxler (2009) recognizes one of the greatest potentials of mobile learning: the dissolution of space and time. 
In the course of time, many different media and technologies have been used to develop this potential. First, we will describe classical approaches that have already attempted to expand the physical learning space. Here the factor of authenticity must always be taken into consideration and to what extent a medium makes authentic learning experiences possible.

Building on this, we will then outline new technologies and teaching methods that gradually increase authenticity and try to dissolve the constant space.

Finally, with mobile immersive learning, we will present a promising possibility that can currently set new standards both in the field of authentic learning experiences and in the expansion of the learning space.

\section{NON-IMMVERSIVE EDUCATIONAL TECHNOLOGIES}

For a long time, pictures have been the window to the world outside of the classroom. The static images make authentic experience possible only to a limited extent, which is why they were replaced in a next step by moving images. The use of videos has a long tradition in education. The time when videocassettes or DVDs have been used in classrooms all over the world is over. Now, all sorts of films with educational purposes are available on online platforms' (Buchner, 2018). For our learners YouTube (web and application) is among the most important educational tools (Hart, 2018). Teachers can use video clips for virtual field trips, visiting Machu Picchu, the African desert or the European Parliament can become reality and this possibility can bring new learning spaces into the everyday classroom (Koumi, 2006). Also the demonstration of dangerous experiments, the revival of long past historical events or the exchange with experts via Skype are possible benefits (Hansch, Hillers, McConachie, Newman, \& Schmidt, 2015). Videos can also expand the temporal component, e.g. when used for a flipped classroom setting. This way students are able to watch the video at home anytime, anywhere and at their own pace (Arnold-Garza, 2014; Bergmann \& Sams, 2012).

The problem with videos is that learners follow a given structure and, apart from the classic navigation options, have little influence on what is shown. Furthermore, videos depict the world only in 2D, which does not correspond to our real perception of life.

\section{AUGMENTED LEARNING}

Mixing real environments with digital representations is known as augmented reality (AR) (Azuma, 1997). AR can be realized through every mobile device with a camera, an existing internet connection and an AR application (Yuen, Yaoyuneyong, \& Johnson, 2011). Visualizing the invisible and seeing the world around us in new ways as well as interacting with this world are the main benefits of AR (Klopfer \& Sheldon, 2010; Sotiriou \& Bogner, 2008). Interaction in this case means the possibility to zoom in and out, watch a 3D model from every perspective and manipulate the depicted digital representations. In class augmented learning for example means that students are engaged into an interactive trip to ancient Egypt. The start-up Areeka has realized this with a magic book including 3D animations that allows students to explore the building process of the pyramids, discover the function of a shadoof or deal with a pharaoh's mask in detail. This book can also be used at home, in the free time or it can be shown to parents or grandparents. Outside the classroom AR allows the reconstruction of historical monuments, which are only preserved in fragments. Figure 1 shows a roman archway overlaid with a digital representation of it. 


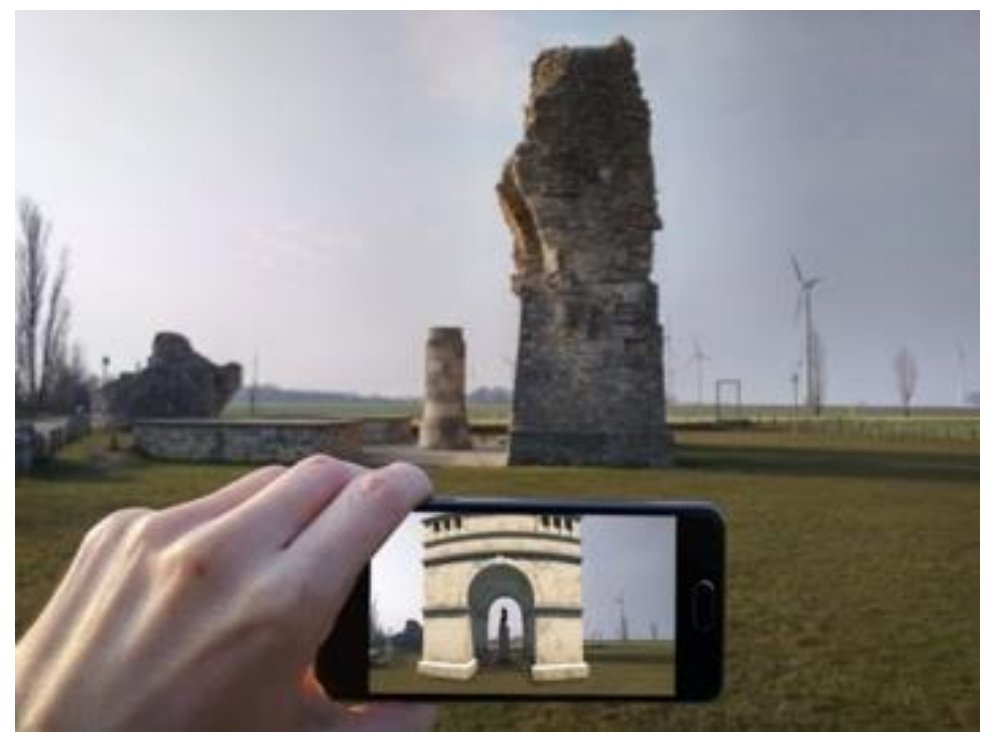

Figure 1. AR in the former roman city Carnuntum, used by permission of the publisher, (C) by 7reasons

In informal learning, AR is widespread. Museums, cultural heritages and tourism boards use AR to find new ways to engage and excite their visitors (Ceynowa, 2012; Kysela \& Štorková, 2015; Ryffel et al., 2017). AR can support both, the extension of time and space by bringing the past to life and through the augmentation of places. Learners then experience totally new worlds just through the lens of their smartphone. A traditional auditorium can be transformed into an interactive laboratory with AR, or a football field into a polluted lake (Squire \& Jan, 2007; Squire \& Klopfer, 2007). Learning with AR can be perceived as very authentic and situated but the feeling of really being in another space is still missing (Dunleavy $\&$ Dede, 2014).

\section{MOBILE IMMERSIVE LEARNING}

Immersion is the feeling of being totally present in a computer-generated world. We know such worlds today as virtual environments (VE) and virtual reality (VR). VE like the social virtual world Second Life allows users to fully engage with a digitally created 3D environment. In contrast to VR, for this experience, no special glasses or head-mounted displays (HMD) are necessary. (de Freitas, Rebolledo-Mendez, Liarokapis, Magoulas, \& Poulovassilis, 2010). Social interactions, control above one's own behavior and the possibility to generate a virtual-self (= Avatar) support the feeling of being totally present in such worlds. If the virtual world is then not only seen as an objective virtual illusion, but as a subjective psychological sense of being in a virtual world, Slater and Wilbur (1997) speak of presence.

Slater et al. (2006) showed that the feeling of presence can be caused via VR. The authors replicated the famous Milgram Experiment and found strong evidence that the participants experienced the treatment as real. With these findings, a door may have opened for more social investigations that are not feasible in real life due to ethical or other considerations. Other studies linked VR with emotions, empathy and of course learning (Dede, 2009; Riva et al., 2007; Shin, 2018). First experiments also showed that people who learned with VR can recall information better compared to a non-VR learning group (Krokos, Plaisant, \& Varshney, 2018). So, the potentials of immersive learning are there and have already been used in different domains. For language learning Barreira et al. (2012) and Chen (2016) are to be mentioned here, for history education Minocha, Tudor, and Tilling (2017) and for the K-12 classroom Merchant, Goetz, Cifuentes, Keeney-Kennicutt, and Davis (2014) provide an overview. As already outlined, VR glasses for schools are not yet affordable due to their high costs. A solution are newly developed technologies and applications that are available on every mobile device. This now makes mobile VR possible, which can also be used by teachers in their classes (Cochrane, 2016). Many of these apps work with $360^{\circ}$ videos which, when used correctly, can also create the feeling of immersion (Aitamurto et al., 2018). One recommendation is the use of headphones, so that the sound of the virtual world can also be perceived. The second one concerns the 
immersion in VR and how this can be realized at a reasonable price in school. With Homido VR Glasses a technically up to date smartphone can be transformed into a VR-capable gadget. Figure 2 shows the Homido, which can easily be attached by means of a holder to mobile phones regardless of brand and size.

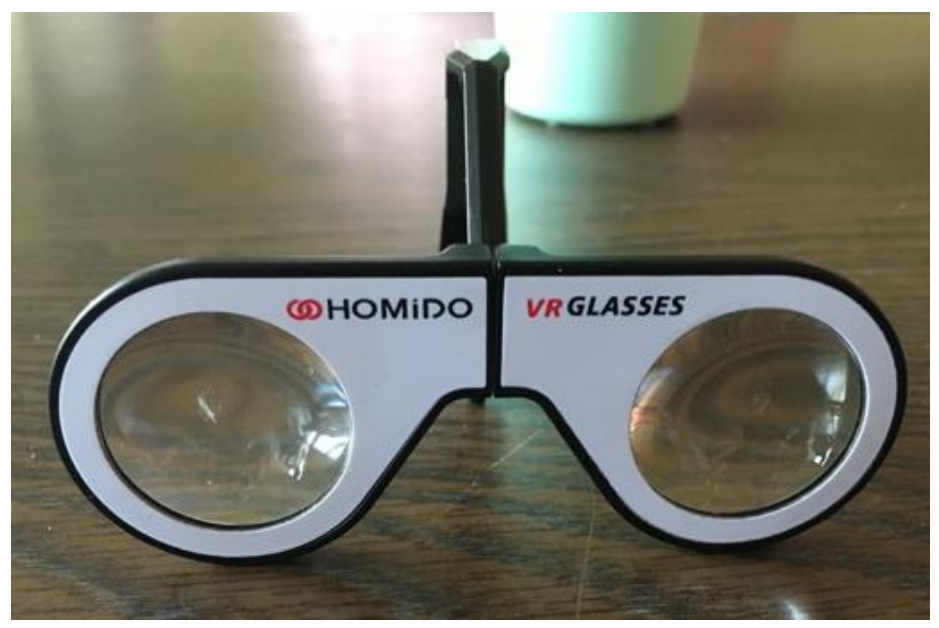

Figure 2. Homido Mini VR Glasses

Simple VR glasses can also be self-made, e.g. by using the manual of Google VR. For example, Google's cardboard can be built in interdisciplinary lessons and then used for virtual excursions in all subjects. Cochrane (2016) notes that by using Google VR Tour Creator, learners can also create VR content themselves. With the panorama function of each photo app, $360^{\circ}$ images can also be created and then transformed into interactive VR environments, e.g. with the online platform Thinglink. We also recommend the CoSpaces Edu app, which allows teachers and learners to build virtual 3D worlds.

The combination of mobile devices and immersive learning worlds now enables mobile immersive learning. Teachers can bring distant or even inaccessible places into the classroom as real authentic experiences. The learning room can be extended without limits, neither spatially nor temporally. In contrast to the seamless learning approach (Looi et al., 2010), photo stories, video documentations or multimedia presentations can now be made not only from the local environment, but also from the visited places. If the theme African Savannah is treated, the children travel there virtually and can capture the vegetation and wildlife there with the photo function. Time also suddenly becomes an influenceable factor. Virtual time travel enables the authentic experience of historical and political events, which can then be reflected upon and discussed in a different way. Such realistic encounters are becoming increasingly important, because the generation of contemporary witnesses to World War II is slowly but surely dying out.

Social learning and exchange are possible through mobile immersive learning when visiting a virtual lecture in Harvard it will be possible to talk to the other students, ask questions to the professor and take part in the discussion related to the lesson topic.

Research-based learning can also be strengthened with the help of mobile immersive learning. Young people can investigate the question of whether life on Mars is possible. But what does it look like there? What do we know about this planet? With the Google Expedition App, it is also possible to visit the surface of the red planet and these questions can be pursued in a completely different way.

\section{CONCLUSION AND FURTHER RESEARCH}

Teachers have always tried to create authentic learning experiences for their learners. Media have been and still are able to make a major contribution to this goal by opening the classroom. Pictures and videos have dominated this opening for a long time, until the development of mobile devices with the power of computers opened up completely new possibilities. Augmented Reality was only the next logical step, which has already provided more authenticity. The space factor can also acquire completely new meanings via AR, for example, when the school courtyard mutates into a medieval marketplace. The currently strongest degree of 
authenticity can be achieved with immersive technologies such as VR. The times when only head-mounted displays allowed immersive experiences are over. With cheap or self-made VR glasses and a mobile device, mobile immersive learning experiences can be realized and used in all fields of education. However, one thing is clear: virtual experiences are not intended to replace real ones, but only to supplement them.

These additions can then perhaps ensure that mobile learning becomes again, what Traxler understands by it: a dissolution of space and time with the consideration of new didactic innovations.

It should also be noted at this point that AR and VR applications are still prone to errors. Learning with these technologies is often considered more difficult compared to traditional media. The problem of attention tunneling can occur as well as dizziness, so-called motion (or simulation) sickness or negative feedback due to the restricted field of vision (Dunleavy \& Dede, 2014; Rupp et al., 2016; Schuemie, van der Straaten, Krijn, \& van der Mast, 2001; Tang, Owen, Biocca, \& Mou, 2003)

Future research must now clarify whether the experience of immersion can actually lead to better or different learning outcomes and how the mentioned challenges can be overcome. What criteria are needed to create authentic situations? Can we then promote pro-social behavior in and with them? Which skills can be trained and how? Moreover, how do immersive learning spaces affect our social behavior in reality?

These and similar questions must be taken up by different scientific fields in the coming years in order to be able to define the conditions for successful mobile immersive learning more closely.

\section{REFERENCES}

Aitamurto, T., Zhou, S., Sakshuwong, S., Saldivar, J., Sadeghi, Y., \& Tran, A. (2018). Sense of Presence, Attitude Change, Perspective-Taking and Usability in First-Person Split-Sphere $360^{\circ}$ Video. In Proceedings of the 2018 CHI Conference on Human Factors in Computing Systems - CHI '18 (S. 1-12). Montreal QC, Canada: ACM Press. https://doi.org/10.1145/3173574.3174119

Arnedillo-Sanchez, I., \& Tangney, B. (2006). Mobile technology towards overcoming technology \& time constrains in digital video production. In P. Isaias, P. Kommers, \& I. Arnedillo-Sanchez (Hrsg.), Mobile learning 2006 (S. 256-259). Dublin, Ireland: International Association for Development of the Information Society Press.

Arnold-Garza, S. (2014). The Flipped Classroom Teaching Model and its use for Information Literacy Instruction. Communications in Information Literacy, 8(1), 7-22. Retrieved from https://mdsoar.org/bitstream/handle/11603/160/260-1481-2-PB.pdf?sequence=1

Azuma, R. (1997). A Survey of Augmented Reality. Teleoperators and Virtual Environments, (6), 355-385.

Barreira, J., Bessa, M., Pereira, L. C., Adao, T., Peres, E., \& y Magahaes, L. (2012). MOW: Augmented Reality game to learn words in different languages: Case study: Learning English names of animals in elementary school. In 7th Iberian Conference on Information Systems and Technologies (CISTI) (S. 1-6).

Bergmann, J., \& Sams, A. (2012). Flip Your Classroom: Reach Every Student in Every Class Every Day. Washington, DC: International Society for Technology in Education.

Buchner, J. (2018). How to create Educational Videos: From watching passively to learning actively. R\&E-Source, 12, 1-10. Retrieved from https://journal.ph-noe.ac.at/index.php/resource/article/view/584

Ceynowa, K. (2012). Information „On the Go“: Innovative Nutzungsszenarien für digitale Inhalte - Die Augmented-Reality-App „Ludwig II.“ der Bayerischen Staatsbibliothek. Bibliothek Forschung und Praxis, 36(1). https://doi.org/10.1515/bfp-2012-0007

Chen, Y. L. (2016). The Effects of Virtual Reality Learning Environment on Student Cognitive and Linguistic Development. The Asia-Pacific Education Researcher, 25(4), 637-646.

Cochrane, T. (2016). Mobile VR in Education: From the Fringe to the Mainstream. International Journal of Mobile and Blended Learning, 8(4), 44-60. https://doi.org/10.4018/IJMBL.2016100104

Cook, J., \& Santos, P. (2016). Three phases of mobile learning state of the art and case of mobile help seeking tool for the health care sector. In D. Churchill, J. Lu, T. K. F. Chiu, \& B. Fox (Hrsg.), Mobile learning design (S. 315-333). Singapore: Springer.

de Freitas, S., Rebolledo-Mendez, G., Liarokapis, F., Magoulas, G., \& Poulovassilis, A. (2010). Learning as immersive experiences: Using the four-dimensional framework for designing and evaluating immersive learning experiences in a virtual world. British Journal of Educational Technology, 4l(1), 69-85. https://doi.org/10.1111/j.14678535.2009.01024.x

Dede, C. (2009). Immersive Interfaces for Engagement and Learning. Science, 323(5910), 66-69.

Duguleana, M., Florin, G., Postelnicu, C., Brondi, R., \& Carrozzino, M. (2016). Exploring Pisa Monuments Using Mobile Augmented Reality. International Journal of Computer and Information Engineering, 10(11), 1938-1941. 
Dunleavy, M., \& Dede, C. (2014). Augmented Reality Teaching and Learning. In J. M. Spector, M. D. Merrill, J. Elen, \& M. J. Bishop (Hrsg.), Handbook of Research on Educational Communications and Technology (S. 735-745). New York, NY: Springer New York. https://doi.org/10.1007/978-1-4614-3185-5_59

Hansch, A., Hillers, L., McConachie, K., Newman, C., \& Schmidt, P. (2015). The Role of Video in Online Learning: Findings From the Field and Critical Reflections, 35. Retrieved from http://www.hiig.de/ wp-content/uploads/2015/02/TopMOOC_Final-Paper.pdf

Kearney, M., Schuck, S., Burden, K., \& Aubusson, P. (2012). Viewing mobile learning from a pedagogical perspective. Research in Learning Technology, 20(1), 1-17. https://doi.org/10.3402/rlt.v20i0.14406

Klopfer, E., \& Sheldon, J. (2010). Augmenting your own reality: student authoring of science-based augmented reality games. New Directions for Youth Development, 128, 85-94.

Koumi, J. (2006). Designing video and multimedia for open and flexible learning. New York: Routledge.

Krokos, E., Plaisant, C., \& Varshney, A. (2018). Virtual memory palaces: immersion aids recall. Virtual Reality. https://doi.org/10.1007/s10055-018-0346-3

Kukulska-Hulme, A. (2005). Introduction. In A. Kukulska-Hulme \& J. Traxler (Hrsg.), Mobile Learning: A Handbook for Educators and Trainers. (S. 1-6). New York: Roudledge.

Kysela, J., \& Štorková, P. (2015). Using Augmented Reality as a Medium for Teaching History and Tourism. Procedia - Social and Behavioral Sciences, 174, 926-931. https://doi.org/10.1016/j.sbspro.2015.01.713

Looi, C.-K., Seow, P., Zhang, B., So, H.-J., Chen, W., \& Wong, L.-H. (2010). Leveraging mobile technology for sustainable seamless learning: a research agenda. British Journal of Educational Technology, 41(2), 154-169. https://doi.org/10.1111/j.1467-8535.2008.00912.x

Merchant, Z., Goetz, E. T., Cifuentes, L., Keeney-Kennicutt, W., \& Davis, T. J. (2014). Effectiveness of virtual reality-based instruction on students' learning outcomes in K-12 and higher education: A meta-analysis. Computers \& Education, 70, 29-40. https://doi.org/10.1016/j.compedu.2013.07.033

Minocha, S., Tudor, A.-D., \& Tilling, S. (2017). Affordances of Mobile Virtual Reality and their Role in Learning and Teaching. In The 31st British Human Computer Interaction Conference, 3rd - 6th July 2017 (S. 1-10). University of Sunderland's St. Peter's Campus, UK. https://doi.org/10.14236/ewic/HCI2017.44

Quinn, C. (2000). mLearning: Mobile, wireless, in your pocket learning. LineZine. Retrieved from http://www.linezine.com/2.1/features/cqmmwiyp.htm

Riva, G., Mantovani, F., Capideville, C. S., Preziosa, A., Morganti, F., Villani, D., ... Alcañiz, M. (2007). Affective Interactions Using Virtual Reality: The Link between Presence and Emotions. CyberPsychology \& Behavior, 10(1), 45-56. https://doi.org/10.1089/cpb.2006.9993

Rupp, M. A., Kozachuk, J., Michaelis, J. R., Odette, K. L., Smither, J. A., \& McConnell, D. S. (2016). The effects of immersiveness and future VR expectations on subjec-tive-experiences during an educational $360^{\circ}$ video. Proceedings of the Human Factors and Ergonomics Society Annual Meeting, 60(1), 2108-2112. https://doi.org/10.1177/1541931213601477

Ryffel, M., Zünd, F., Aksoy, Y., Marra, A., Nitti, M., Aydın, T. O., \& Sumner, B. (2017). AR MUSEUM: A MOBILE AUGMENTED REALITY APPLICATION FOR INTERACTIVE PAINTING RECOLORING. In Multi Conference on Computer Science and Information Systems 2017 (S. 7). Lisbon, Portugal.

Schuemie, M. J., van der Straaten, P., Krijn, M., \& van der Mast, C. A. P. G. (2001). Research on Presence in Virtual Reality: A Survey. CyberPsychology \& Behavior, 4(2), 183-201. https://doi.org/10.1089/109493101300117884

Sharples, M., Arnedillo-Sanchez, I., Milrad, M., \& Vavoula, G. (2009). Mobile Learning: Small Devices, Big Issues. In N. Balacheff, S. Ludvigsen, T. de Jong, A. Lazonder, \& S. Barnes (Hrsg.), Technology-Enhanced Learning: Principles and products (S. 233-249). Dordrecht: Springer Netherlands. https://doi.org/10.1007/978-1-4020-9827-7

Shin, D. (2018). Empathy and embodied experience in virtual environment: To what extent can virtual reality stimulate empathy and embodied experience? Computers in Human Behavior, 78, 64-73. https://doi.org/10.1016/j.chb.2017.09.012

Slater, M., Antley, A., Davison, A., Swapp, D., Guger, C., Barker, C., ... Sanchez-Vives, M. V. (2006). A Virtual Reprise of the Stanley Milgram Obedience Experiments. PLoS ONE, 1(1), 1-10. https://doi.org/10.1371/journal.pone.0000039

Slater, M., \& Wilbur, S. (1997). A Framework for Immersive Virtual Environments (FIVE): Speculations on the Role of Presence in Virtual Environments. Presence: Teleoperators and Virtual Environments, 6(6), $603-616$. https://doi.org/10.1162/pres.1997.6.6.603

Sotiriou, S., \& Bogner, F. X. (2008). Visualizing the invisible: augmented reality as an innovative science education scheme. Advanced Science Letters, 1, 114-122.

Squire, K., \& Jan, M. (2007). Mad City Mystery: Developing Scientific Argumentation Skills with a Place-based Augmented Reality Game on Handheld Computers. Journal of Science Education and Technology, 16(1), 5-29. https://doi.org/10.1007/s10956-006-9037-z 
Squire, K., \& Klopfer, E. (2007). Augmented Reality Simulations on Handheld Computers. The Journal of the Learning Sciences, 16(3), 371-413.

Stevenson, B., Länsitie, J., Kogler, C., \& Bauer, P. (2015). Exploring Co-Creation of Educational Videos in an International Collaborative Context, 11(2), 10.

Tang, A., Owen, C., Biocca, F., \& Mou, W. (2003). Comparative Effectiveness of Augmented Reality in Object Assembly. NEW HORIZONS, (5), 8.

Traxler, J. (2009). Learning in a mobile age. International Journal of Mobile and Blended Learning, 1(1), 1-12.

Traxler, J. (2016). What killed the mobile learning dream? Retrieved from https://www.jisc.ac.uk/inform-feature/ what-killed-the-mobile-learning-dream-26-feb-2016?

Yuen, S. C.-Y., Yaoyuneyong, G., \& Johnson, E. (2011). Augmented Reality: An Overview and Five Directions for AR in Education. Journal of Educational Technology Development and Exchange, 4(1). https://doi.org/10.18785/jetde.0401.10 